\title{
EDITORIAL
}

\section{A BRIEF ENCOMIUM}

I have read Horizons from its inception and have more recently participated in its life as a reader of submissions. I mention my involvement up front to signal my ties with the journal since I intend to praise it.

There are three reasons why Horizons deserves hosannas.

First, from its beginnings, Horizons has adroitly balanced high standards of scholarship and the pedagogical needs of the classroom teacher. In performing that delicate act it has reflected more perfectly than any other activity of the College Theology Society the selfannounced aim of the society to balance learning and teaching. A quick perusal of back issues makes the point: it is hard to think of any single article published in these pages which is so preciously arcane as to be useless for people in the classroom. It is very easy to signal many articles which provide full nourishment for the many different interests of the society. My own scholarly interests are relatively narrow but it is a rare issue of Horizons that I fail to read cover to cover. Could anyone say the same of most scholarly journals of religion now being published in the United States which, on examination, seem increasingly to treat abundanter de parvo?

Next, Horizons represents a tradition. However ecumenical our membership there is something unremittingly Catholic to its substance. I use that term "Catholic" both generously to indicate the journal's openness and narrowly to circumscribe that tradition which is sacramental, realist, iconic, communitarian, and, yes, petrine. In that sense Horizons has not only been an arena for the dissemination of scholarly information but a vehicle for the ongoing process of aggiornamento. The journal may not have solved the seemingly intractable crux of theology versus religious studies but it has creatively worked at the intersection of that crux.

Finally, Horizons has nurtured the College Theology Society by providing its membership with a means of both disseminating knowledge and provoking scholarly debate. Together with the annual volume and the presentations at the convention Horizons has been a source of encouragement and a place of learning. It has expanded the individual's work by providing a forum for sharing. The scholarly sharing of which I speak will be increasingly more important in the coming years as fiscal constraints and other structural problems of higher education erode the means for greater scholarly collegiality.

The future success of this journal will depend on the willingness of the many to labor as unselfishly for the common good of both the journal and society as have Messrs. Van Allen and Prusak, the founding co- 
editors. We need to see evidences of that labor at various tasks of the journal's life if the standards are to be maintained at the level they now enjoy. I have every confidence that such will be the case.

—LAWRENCE S. CUNNINGHAM 